\title{
New perspectives of biomarkers for the management of chronic hepatitis B
}

\author{
Chih-Lin Lin, ${ }^{1,2}$ Jia-Horng Kao $3,4,5,6$ \\ 'Department of Gastroenterology, Renai branch, Taipei City Hospital; ${ }^{2}$ Department of Psychology, National Chengchi University; \\ ${ }^{3}$ Graduate Institute of Clinical Medicine, College of Medicine, National Taiwan University; ${ }^{4}$ Department of Internal Medicine, ${ }^{5} \mathrm{Hepatitis}$ \\ Research Center, National Taiwan University Hospital; ${ }^{6}$ Department of Medical Research, National Taiwan University, National Taiwan \\ University Hospital, Taipei, Taiwan.
}

With recent advances in molecular and genomic investigations, the impact of hepatitis B viral and host factors on the progression of chronic HBV infection has been explored. For viral factors, hepatitis B viral load is a strong predictor for liver disease progression. Hepatitis B viral kinetics appear to be important for successful anti-viral therapy. Serum HBsAg level serves as a complementary marker to viral load for the prediction of HBV-related adverse outcomes in patients with low viral load. In those with low viral load, high serum HBsAg level is associated with higher risks of cirrhosis and $\mathrm{HCC}$. Hepatitis B core-related antigen ( $\mathrm{HBCrAg}$ ) induces host immune responses, and the reduction of the $\mathrm{HBcrAg}$ level as well as the increment of total anti-HBc level are significantly associated with favorable outcomes. HBV genotypes (genotype $C / D$ ) and mutants (basal core promoter and deletion mutation in pre-S genes) are well known viral genetic markers to predict disease progression. For host factors, serum inflammatory biomarkers have been developed to evaluate the HBV-associated hepatic necroinflammation and fibrosis. Host single nucleotide polymorphism on sodium taurocholate cotransporting polypeptide (NTCP, an HBV entry receptor) may be associated with a decreased risk for cirrhosis and HCC. In conclusion, patients with chronic hepatitis B should be evaluated with relevant viral and host markers to identify those who are at a higher risk of liver disease progression and then receive timely antiviral therapy. (Clin Mol Hepatol 2016;22:423-431)

Keywords: Chronic hepatitis B; HBV DNA; HBsAg; HBcrAg; Total anti-HBC

\section{INTRODUCTION}

Despite the availability of effective hepatitis B virus (HBV) vaccine for more than three decades, HBV is still an important public health problem and the leading cause of chronic hepatitis, cirrhosis, and hepatocellular carcinoma (HCC) worldwide. ${ }^{1,2}$ Although most of chronic hepatitis B (CHB) patients have favorable clinical outcomes, HBV eventually leads to develop cirrhosis, liver failure, or HCC in a significant proportion of patients. ${ }^{3}$ Through the development of effective anti-HBV treatment, the prevention of disease progression and reduction of HCC risk in patients with chronic HBV infection have been achieved. ${ }^{4}$ However, the optimal timing and the strategy of antiviral therapy toward HBV cure are still daunting challenges ahead. With recent advances in molecular investigations, several biomarkers associated with the natural history of chronic HBV infection and the efficacy of antiviral therapy

\footnotetext{
Abbreviations:

$A L T$, alanine aminotransferase; APRI, aspartate aminotransferase to platelet ratio index; $\mathrm{BCP}$, basal core promoter; $\mathrm{CHB}$, chronic hepatitis B; ERADICATE-B, Elucidation of risk factors for disease control or advancement in Taiwanese hepatitis $B$ carriers; $\mathrm{HBCAg}$, hepatitis B core antigen; HBcrAg, Hepatitis B virus core-related antigen; HBeAg, hepatitis B e antigen; HBsAg, Hepatitis B surface antigen; HBV, Hepatitis B virus; HCC, hepatocellular carcinoma; NTCP, Sodium taurocholate cotransporting polypeptide; REVEAL-HBV, Risk evaluation of viral load elevation and associated liver disease/cancer-hepatitis B virus; SNP, single nucleotide polymorphism
}

\section{Corresponding author : Jia-Horng Kao}

Graduate Institute of Clinical Medicine, National Taiwan University College of Medicine, 1 Chang-Te St., Taipei 10002, Taiwan

Tel: +886-2-23123456 ext. 67307, Fax: +886-2-23825962

E-mail:kaojh@ ntu.edu.tw 
Clin Mol Hepatol

Volume 22 Number 4 December 2016

have been identified. ${ }^{5-7}$ Integration of these biomarkers may improve our understanding about the natural history of $\mathrm{CHB}$ and the response to antiviral therapy. In this article, a new perspective of biomarkers for the management of $\mathrm{CHB}$ will be reviewed and discussed.

\section{HBV BIOMARKERS ASSOCIATED WITH PRO- GRESSION OF CHB}

The natural history of HBV carriers who are infected early in life can be divided into 4 dynamic phases based on the virus-host interaction. ${ }^{1,6}$ During the immune tolerance phase, extensive liver replication of HBV results in high HBV DNA levels (usually higher than $10^{8} \mathrm{IU} / \mathrm{mL}$ ) and hepatitis $B$ e antigen (HBeAg) is present. Hepatitis activities are low with normal or mildly elevated serum alanine aminotransferase (ALT) levels in this phase. After 2 to 3 decades of persistent infection, the infection enters the immune clearance phase. HBV carriers have bouts of acute hepatitis flare accompany with the elevation of ALT level and the decline of serum HBV DNA level. The majority of carriers seroconvert from $\mathrm{HBeAg}$ to anti-HBe in this phase. However, following a series of hepatitis flare, the liver starts to have cirrhotic changes. The incidence of cirrhosis has been shown to be $2 \%$ per year, depending on the severity and extent of hepatic inflammation. ${ }^{8,9}$ After $\mathrm{HBeAg}$

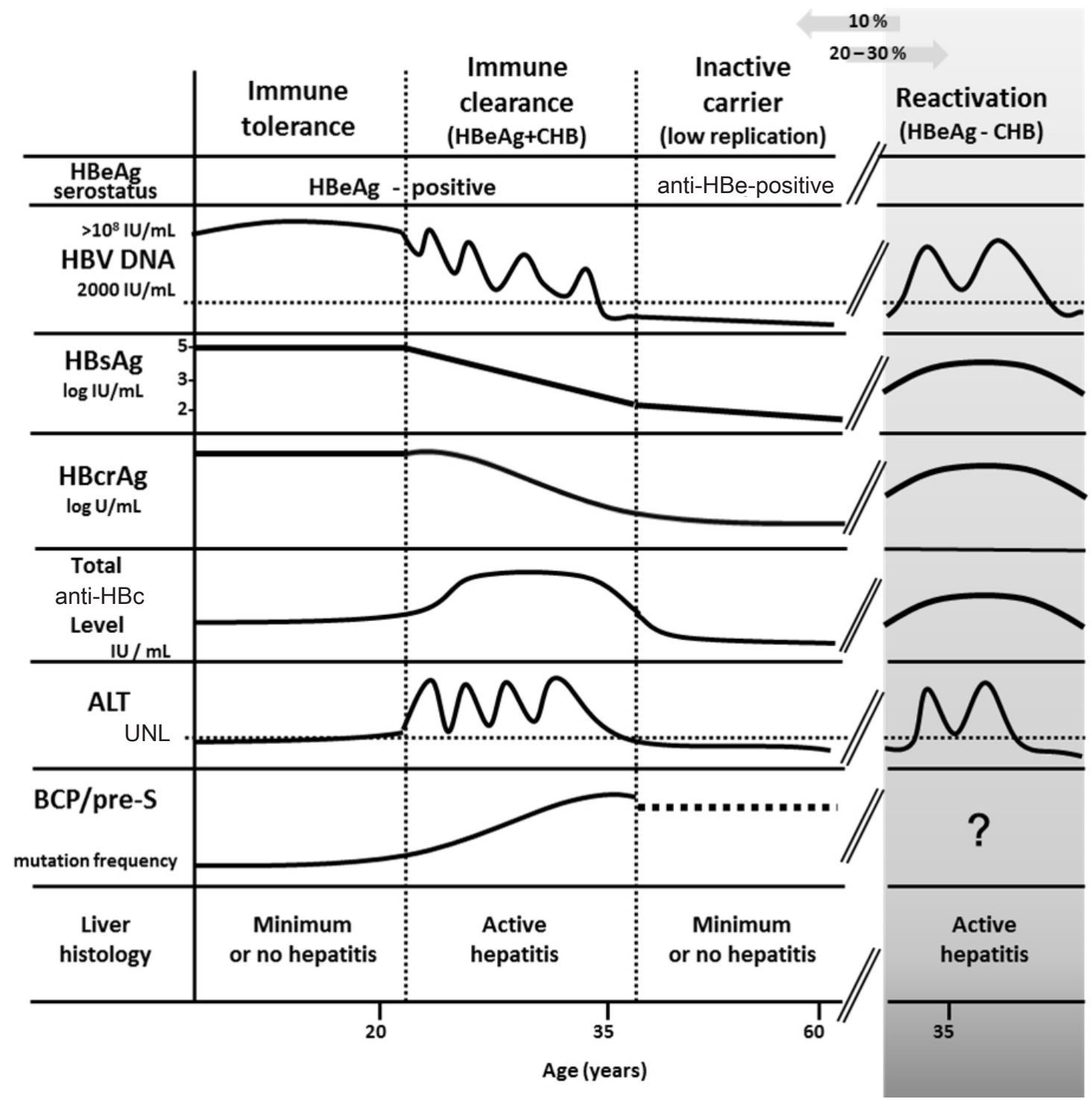

Figure 1. The natural history of chronic hepatitis B by integrating hepatitis B viral and host biomarkers. Modified from Yang, et al. ${ }^{6}$ 
seroconversion, patients are usually in the residual or low replication phase, with low HBV DNA level (less than 2,000 IU/mL) and normal ALT, and even Hepatitis B surface antigen (HBsAg) seroclearance. Unfortunately, a small but significant proportion of patients continue to have moderate level of HBV DNA and active liver disease designated reactivation phase. ${ }^{10}$ The frequency and severity of hepatitis flares during the immune clearance and/or reactivation phase predicts progression of liver disease. In general, early HBeAg seroconversion with subsequent HBsAg loss or seroconversion typically confers a favorable outcome, whereas late or absent HBeAg seroconversion after multiple hepatitis flares may accelerate the progression of chronic hepatitis to cirrhosis, and therefore, has a poor clinical outcome.

In real world practice, the clinical courses of CHB vary greatly among individuals. Recent cohort studies on Asian populations even showed that HCC still occurred in patients with spontaneous HBsAg clearance. ${ }^{11,12}$ Therefore, accurate determination of the clinical phases of a given HBV patient is clinically mandatory. Currently, several biomarkers affecting clinical outcomes of CHB have been identified. By integration of these biomarkers, the nature history of CHB could be revisited (Fig. 1). ${ }^{6}$

\section{HEPATITIS B VIRAL LOAD}

Based on a population-based cohort of untreated CHB Taiwanese patients, the risk evaluation of viral load elevation and associated liver disease/cancer-hepatitis B virus (REVEAL-HBV) study first demonstrated that the cumulative incidence of HCC is correlated with serum hepatitis B viral load in a dose dependent manner. ${ }^{13,14}$ The relative risk of HCC began to increase from HBV DNA level of 2,000 IU/mL to HBV DNA levels of 200,000 IU/mL. Several cross sectional and longitudinal cohort studies in Taiwan, Hong Kong, and China also confirmed the impact of HBV DNA level on HCC development. ${ }^{15-20}$ In addition, several clinical trials revealed that a lower baseline HBV DNA level was predictive of HBeAg loss or seroconversion as well as viral suppression in patients receiving anti-viral therapy. ${ }^{5}$ These lines of evidence indicate that measurements of HBV viral load may define which CHB patients are at an increased risk of liver disease progression.

\section{QUANTITATIVE HBsAg LEVEL}

$\mathrm{HBsAg}$ is a well established biomarker of HBV infection and is qualitatively used for the diagnosis of HBV infection in our daily practice. In the natural course of CHB, HBV DNA is only from mature infectious particles and its level reflects viral replication. Accordingly, a decline of HBV DNA means the reduction of HBV replication. In addition, HBsAg can also be derived from defective subviral particles. Thus, serum HBsAg level not only reflects the ccCDNA transcription or mRNA translation, but also host immune control over HBV infection. ${ }^{21,22}$ The combination of low serum HBsAg level and serum HBV DNA level can predict inactive HBV carrier status and HBsAg loss after HBeAg seroconversion. ${ }^{23,24}$ Our previous study showed that serum HBsAg level was better than serum HBV DNA level for the prediction of spontaneous HBsAg loss in HBeAg-negative carriers with a low viral load ( $<2,000 \mathrm{IU} /$ $\mathrm{mL}$ ). Moreover, serum HBsAg level $<10 \mathrm{IU} / \mathrm{mL}$ was the strongest predictor of HBsAg loss in patients with a low viral load. ${ }^{25}$

The association between serum HBsAg level and HCC has been elucidated in both community-based and hospital-based cohort studies. In the community-based cohort study (REVEAL-HBV study), serum HBsAg and HBV DNA levels were independent predictors of HCC development in HBV carriers. Serum HBsAg level was complementary to HBV DNA level in stratifying HCC risks, especially in patients with $\mathrm{HBV}$ DNA level $<200,000 \mathrm{IU} / \mathrm{mL}{ }^{26}$ In our hospital-based ERADICATE-B study (Elucidation of Risk Factors for Disease Control or Advancement in Taiwanese Hepatitis B Carriers), elevated HBV DNA and HBsAg levels were positively associated with $\mathrm{HCC}$ development in a dose-response manner in patients with HBV DNA levels $>2,000 \mathrm{IU} / \mathrm{mL} .{ }^{27}$ Although the incidence of $\mathrm{HCC}$ is significantly associated with baseline serum HBV-DNA level, inactive or low risk HBV carriers (serum HBV-DNA levels $<2,000 \mathrm{IU} / \mathrm{mL}$ ) still have significantly higher hazard ratios for HCC compared with individuals without HBV infection. ${ }^{28}$ Therefore, it is important to identify factors predictive of HCC other than HBV DNA level in these inactive or low risk HBV carriers. In the ERADICATE-B study, among 1,068 HBeAg-negative patients with HBV DNA levels $<2000 \mathrm{IU} / \mathrm{mL}$, the HCC risk significantly increased in those with $\mathrm{HBs} A g$ level $\geq 1000 \mathrm{IU} / \mathrm{mL}$ compared with those with $\mathrm{HBs} A g$ level $<1,000 \mathrm{IU} / \mathrm{mL}$. Multivariate analysis revealed that $\mathrm{HBsAg}$ level $\geqq 1,000 \mathrm{IU} / \mathrm{mL}$ was an independent risk factor for HCC development. ${ }^{27}$ Data from REVEALHBV study and ERADICATE-B study all showed that serum HBsAg and HBV DNA levels were complementary markers in predicting disease progression, including hepatitis flares, HBeAg-negative hepatitis, liver cirrhosis, and HCC. ${ }^{27,29,30}$

Despite using immunoprophylaxis to interrupt mother-to-infant HBV transmission in clinical practice, mothers positive for $\mathrm{HBeAg}$ 
with a high viral load are the major causes of immunoprophylactic failure. ${ }^{31}$ Furthermore, quantitative maternal HBsAg predicts infection in infants as well as maternal viral load does. Estimated rates of infection at maternal HBsAg levels of $4,4.5$, and $5 \log _{10}$ $\mathrm{IU} / \mathrm{mL}$ were $2.4 \%, 8.6 \%$, and $26.4 \%$. $^{32}$ Thus, antiviral therapy may be considered in pregnant women with high HBsAg level as well as high viral load to interrupt mother-to-infant transmission. ${ }^{33}$

\section{HEPATITIS B CORE-RELATED ANTIGEN LEVEL}

Hepatitis B virus core-related antigen ( $\mathrm{HBcrAg}$ ) is comprised of hepatitis $B$ core antigen ( $\mathrm{HBCAg}), \mathrm{HBeAg}$ and a precore protein (p22cr) coded with the precore/core region. ${ }^{34} \mathrm{HBcAg}$ is an inner nucleocapsid surrounding the viral DNA. HBeAg is a circulating peptide derived from the core gene, then modified and secreted from liver cells. Both $\mathrm{HBCAg}$ and $\mathrm{HBeAg}$, sharing an identical 149 amino acid sequence, are the target of cytotoxic T-cell. Thus, HBcrAg can induce host cellular immune response. During follow-up of $\mathrm{HBeAg}$-positive patients, the reduction in the HBcrAg levels is significantly associated with spontaneous $\mathrm{HBeAg}$ seroconversion. ${ }^{35}$ Previous reports indicated that serum HBcrAg concentration is closely correlated with serum HBV DNA as well as intrahepatic cccDNA level. ${ }^{36-38}$ Therefore, HBcrAg may help determine the phase of HBV infection. In a large European cohort mainly infected with HBV genotypes A or D, the median serum HBcrAg levels were high in the immune tolerance and immune clearance phases (>8 $\log \mathrm{U} / \mathrm{mL}$, respectively), lower in $\mathrm{HBeAg}$-negative chronic hepatitis (4.82 log $\mathrm{U} / \mathrm{mL}$ ) but very low in HBeAg-negative inactive carriers (only $2.00 \log \mathrm{U} / \mathrm{mL}$ ). ${ }^{39}$ Furthermore, recent studies revealed that serum HBcrAg level was associated with development of HCC in both nucleos(t)ide analogue-treated and untreated patients. ${ }^{40-42}$ In a large cohort study, $\mathrm{HBcrAg}>2.9 \log \mathrm{U} / \mathrm{mL}$ (HR, 5.05; $95 \% \mathrm{Cl}, 2.40-10.63)$ was associated with the incidence of HCC. Of particular note, time-dependent ROC analysis showed that HBcrAg was superior to HBV DNA in predictive power for HCC development throughout the follow-up period. ${ }^{42}$

\section{TOTAL ANTI-HBC LEVEL}

Pathogenesis of HBV infection related to the interactions between host immune responses and HBV-encoded antigens. Immunoglobulin antibody to $\mathrm{HBCAg}$ is the first antibody to appear after infection, in the sequence of immunoglobulin $\mathrm{M}$ anti-HBC
(IgM anti-HBC) followed by Immunoglobulin G anti-HBC (IgG anti$\mathrm{HBC}$ ). A novel assay for the quantification of total anti-HBC antibodies has been developed. ${ }^{43}$ In the natural history of chronic HBV infection, total anti-HBc levels in the immune clearance and reactivation phases are significantly higher than those in the immune tolerance and inactive carrier phases. Although patients at the immune-tolerant phase have very high levels of HBV DNA, the total anti-HBC levels are similar to those of inactive carriers. ${ }^{44}$ In addition, the baseline total anti-HBc levels could predict $\mathrm{HBeAg}$ seroconversion in $\mathrm{HBeAg}$-positive $\mathrm{CHB}$ patients receiving antiviral therapy. Patients with higher baseline total anti-HBc levels exhibited a higher rate of $\mathrm{HBeAg}$ seroconversion. ${ }^{45,46}$ Accordingly, total anti-HBC level is suggested to correlate with the host immune responses against HBV and maybe complementary to current quantitative viral markers, including HBsAg and HBV DNA levels.

\section{HBV GENOTYPE}

According to the divergence in the entire HBV genomic sequences, at least $10 \mathrm{HBV}$ genotypes (A to J) have been defined with specific geographical distributions. ${ }^{47,48}$ For example, Genotype $A$ and $D$ are prevalent in Africa, Europe, India and America. Genotypes $B$ and $C$ are most common in Asia-Pacific region. Genotype $E$ is restricted to West Africa. Genotype $F$ is found in Central and South America. Several studies suggested that HBV genotype can influence the long-term outcomes of HBV infection. HBV genotype $C$ and $D$ patients, compared to genotype $A$ and $B$ patients, have late or absent HBeAg seroconversion. ${ }^{49-52}$ Patients with genotype C HBV infection have a higher risk of cirrhosis and HCC than those with genotype B infection. ${ }^{47,48,53,54}$ Of interest, several reports have shown that HBV genotype $B$ was associated with $\mathrm{HCC}$ development in young non-cirrhotic patients. Whereas genotype C was associated with HCC development in old cirrhotic patients. ${ }^{51,53,55}$ The possible influence of other genotypes on the natural history of HBV infection remains limited. Early studies reported that HCC was more frequent in patients with HBV genotype $D$ and $F$ infection than those with genotype $A$ infection. ${ }^{56,57}$ Recent cohort study from Gambia, where genotype E prevail, revealed that the annual incidence of $\mathrm{HBeAg}$ and $\mathrm{HBsAg}$ seroclearance were similar to other genotypes (7.4 and $1.0 \%$, respectively). However, the incidence rate of HCC in treatment-naive male chronic HBV carriers in Gambia was higher than Europe but lower than in East Asia. ${ }^{58}$ 


\section{HBV MUTANTS}

Because HBV lacks the ability of proofreading for the spontaneous error of viral replication through reverse transcription, HBV mutant strains occur during the natural course of infection as well as with anti-viral therapy. The common mutations in core promoter and deletion mutation in pre-S/S genes have been reported to be associated with the progression of liver disease, including cirrhosis and HCC. Previous studies revealed that dual mutations in basal core promoter (BCP) A1762T/G1764A were strongly associated with the risk of HCC development. ${ }^{17,18,59-62}$ BCP A1762T/ G1764A mutants also served as a quantitative viral marker for cirrhosis development. In our ERADICATE-B study, quantitative analysis using pyrosequencing revealed that risk of cirrhosis was higher in patients with BCP A1762T/G1764A mutants $\geq 45 \%$ compared to $<45 \%$. ${ }^{63}$

Deletion mutations in the pre- $S$ gene frequently occur in chronic HBV infection. The deletion over pre-S gene may cause accumulation of large surface protein in the endoplasmic reticulum (ER), resulting in ER stress and hepatocarcinogenesis. ${ }^{64,65}$ Previous studies revealed that the presence of pre-S deletion mutations was an independent risk factor associated with the development of cirrhosis and HCC over time. ${ }^{66-68}$ Meta-analysis studies also confirmed that pre-S deletion mutations are associated with HCC risk. ${ }^{62,69}$

\section{HOST INFLAMMATORY BIOMARKERS}

In the course of chronic hepatitis B, necroinflammation along with architectural changes of the liver parenchyma often leads to hepatic fibrogenesis. The severity of hepatic fibrosis is one of the important prognostic factors in $\mathrm{CHB}^{70}$ With the limitations of liver biopsy, several non-invasive biomarkers, such as aspartate aminotransferase to platelet ratio index (APRI), FIB-4 index, FibroTest, Forns test, hepascore, have been developed to assess hepatic necroinflammation and fibrosis. ${ }^{71}$ Among these biochemical indices, both APRI and FIB-4 index can be measured by using parameters from routine laboratory tests. In our recent study, the correlation between APRI, FIB-4 and histologic severity of 631 CHB patients was assessed. Areas under receiver operating characteristic curves of APRI and FIB-4 demonstrated moderate discriminatory power for the diagnosis of significant fibrosis and cirrhosis. Of particular note, our study showed that the diagnostic ability of FIB-4 was better than APRI. By applying FIB-4 index, significant fibrosis could be accurately excluded in $69.2 \%$ and presence of cirrhosis could be diagnosed in $84.4 \%$ of patients. Furthermore, $62 \%$ of patients could be identified correctly without performing invasive liver biopsy. ${ }^{72}$ Recently, through comprehensive metabolomic profiling method, serum metabolite biomarkers were established for CHB stage stratification. A novel metabolite biomarker, PIPS index, based on phosphatidylinositol and phosphatidylserine, has high discriminatory power for the detection of early inflammation and fibrosis in CHB patients. ${ }^{73}$ Taken together, serum inflammatory biomarker may serve as useful noninvasive methods to evaluate the severity of hepatic necroinflammation and fibrosis in CHB patients.

\section{HOST GENETIC MARKERS}

Not only hepatitis B viral factors associated with HCC are identified, host genetic variations also affect the long-term outcome of $\mathrm{CHB}$. Although research on the natural history of $\mathrm{CHB}$ has made remarkable progress, host genetic factors associated with disease progression of CHB have not well addressed yet. ${ }^{74}$ In a large cohort study, including patients with $\mathrm{CHB}$, a single nucleotide polymorphism (SNP) (rs12979860) in the intronic region of interferon- $\lambda 4$ is a strong predictor of hepatic fibrosis progression. ${ }^{75}$

Through genome-wide association studies, two SNPs, rs3077 near HLA-DPA1 region and rs9277535 near HLA-DPB1 region, have been shown to be associated with HBV persistence after acute HBV infection. ${ }^{76}$ Our case-control study demonstrated that HBeAg-negative patients with rs9277535 non-GG genotype had a higher likelihood of spontaneous HBsAg seroclearance (Odds ratio: $1.83,95 \%$ confidence interval: $1.04-3.21, P=0.034) .{ }^{77}$

Sodium taurocholate cotransporting polypeptide (NTCP) has been identified as either the receptor or part of the receptor complex for HBV infection. ${ }^{78}$ NTCP is encoded by the SLC10A1 gene, locates on chromosome 14. Recently, the association between SNP, the p.Ser267Phe (S267F) variant (rs2296651), on NTCP and $\mathrm{HBV}$ related cirrhosis and HCC has been determined. A genetic association study in a large cohort of patients with CHB in Taiwan demonstrated that S267F was significantly associated with decreased risk for cirrhosis and HCC. In addition, patients with undetectable HBV DNA and the GA or AA genotypes of S267F variant had a 25-fold decreased risk of developing HCC than patients with high viremia who carried the GG genotype. ${ }^{79}$ Therefore, the S267F variant may serve as a genetic marker to identify CHB patients with very low risk of developing HCC. 
Table 1. Hepatitis B viral and host factors associated with prognosis of chronic hepatitis B

\begin{tabular}{ll}
\multicolumn{1}{c}{ Viral biomarkers } & \multicolumn{1}{c}{ Host biomarkers } \\
\hline High serum level of HBV DNA/HBsAg/ HBcrAg & High score of inflammatory biomarkers (APRI, FIB-4, metabolite biomarker) \\
Low serum level of total anti-HBC & Host genetic markers \\
HBV genotype C/D/F & rs 12979860 in the intronic region of interferon- $\lambda 4$ \\
BCP A1762T/G1764A mutation & rs2296651 (S267F) GG genotype on NTCP \\
Pre-S deletion mutation & Hypermethylation of HOXA2 and HDAC4 \\
& Hypomethylation of PPP1R18 \\
\hline
\end{tabular}

Epigenetic change, the DNA methylation, reflects an interaction between genetic background and cellular microenvironment. DNA methylation might also contribute to the downregulation of gene expression, which may link to liver disease progression. ${ }^{80}$ Recently, through hepatic genome-wide methylation profiling, hypermethylation of HOXA2 and HDAC4 along with hypomethylation of PPP1R18 were identified and significantly linked to severe fibrosis in patients with CHB. cytosine-guanine dinucleotide methylation within HOXA2, PPP1R18 and HDAC4 genes might serve as genetic markers for progression of $\mathrm{CHB}^{81}$

\section{CONCLUSIONS}

Over the past decade, through meticulous investigations on the molecular epidemiology of HBV, several hepatitis B viral biomarkers, including HBV viral load, quantitative HBsAg, HB$\mathrm{CrAg}$, anti-HBc levels and HBV genotype/mutants have been shown to affect the long-term outcomes of patients with chronic HBV infection. In addition, the role of host factors in HBV-related liver disease progression, such as liver inflammation status, genetic variation and epigenetically modified genes have also been increasingly recognized. On the basis of these emerging data (Table 1), patients with CHB should be evaluated and monitored with relevant viral and host biomarkers to identify those who have a higher risk of liver disease progression and receive timely effective antiviral therapy.

\section{Funding support}

This work was supported by grants from the National Taiwan University Hospital, the Ministry of Health and Welfare, and the Ministry of Science and Technology, Executive Yuan, Taiwan.

\section{Conflicts of Interest}

The authors have no conflicts to disclose.

\section{REFERENCES}

1. Kao JH, Chen DS. Global control of hepatitis B virus infection. Lancet Infect Dis 2002;2:395-403.

2. Kao JH. Hepatitis B vaccination and prevention of hepatocellular carcinoma. Best Pract Res Clin Gastroenterol 2015;29:907-917.

3. Fattovich G, Bortolotti F, Donato F. Natural history of chronic hepatitis B: special emphasis on disease progression and prognostic factors. J Hepatol 2008;48:335-352.

4. Lin $\mathrm{CL}$, Kao JH. Perspectives and control of hepatitis B virus infection in Taiwan. J Formos Med Assoc 2015;114:901-909.

5. Lin $\mathrm{CL}$, Kao JH. Hepatitis $B$ viral factors and treatment responses in chronic hepatitis B. J Formos Med Assoc 2013;112:302-311.

6. Yang HC, Kao JH. Revisiting the natural history of chronic HBV infection. Curr Hepatol Rep 2016;15:141-149.

7. Yang $\mathrm{HC}, \mathrm{KaO} J \mathrm{H}$. Looking into the crystal ball: biomarkers for outcomes of HBV infection. Hepatol Int 2016;10:99-101.

8. Kao JH. Hepatitis B virus genotypes and hepatocellular carcinoma in Taiwan. Intervirology 2003;46:400-407.

9. Liaw YF, Chu CM. Hepatitis B virus infection. Lancet 2009;373:582592.

10. Chu CM, Liaw YF. Predictive factors for reactivation of hepatitis B following hepatitis $B$ e antigen seroconversion in chronic hepatitis $B$. Gastroenterology 2007;133:1458-1465.

11. Liu J, Yang HI, Lee $M H$, Lu SN, Jen CL, Batrla-Utermann $R$, et al; Spontaneous seroclearance of hepatitis B seromarkers and subsequent risk of hepatocellular carcinoma. Gut 2014;63:1648-1657.

12. Kim GA, Lee HC, Kim MJ, Ha Y, Park EJ, An J, et al. Incidence of hepatocellular carcinoma after HBsAg seroclearance in chronic hepatitis B patients: A need for surveillance. J Hepatol 2015;62:10921099.

13. Chen CJ, Yang HI, Su J, Jen CL, You SL, Lu SN, et al. Risk of hepatocellular carcinoma across a biological gradient of serum hepatitis $B$ virus DNA level. JAMA 2006;295:65-73.

14. Iloeje UH, Yang HI, Su J, Jen CL, You SL, Chen CJ. Risk Evaluation of Viral Load Elevation and Associated Liver Disease/Cancer-In HBV (the REVEAL-HBV) Study Group. Predicting liver cirrhosis risk based on the level of circulating hepatitis B viral load. Gastroenterology 2006;130:678-686. 
15. Wong VW, Chan SL, Mo F, Chan TC, Loong HH, Wong GL, et al. Clinical scoring system to predict hepatocellular carcinoma in chronic hepatitis B carriers. J Clin Oncol 2010;28:1660-1665.

16. Yuen MF, Tanaka Y, Fong DY, Fung J, Wong DK, Yuen JC, et al. Independent risk factors and predictive score for the development of hepatocellular carcinoma in chronic hepatitis B. J Hepatol 2009;50:8088.

17. Liu CJ, Chen BF, Chen PJ, Lai MY, Huang WL, Kao JH, et al. Role of hepatitis B viral load and basal core promoter mutation in hepatocellular carcinoma in hepatitis B carriers. J Infect Dis 2006;193:12581265.

18. Liu CJ, Chen BF, Chen PJ, Lai MY, Huang WL, Kao JH, et al. Role of hepatitis $B$ virus precore/core promoter mutations and serum viral load on noncirrhotic hepatocellular carcinoma: a case-control study. J Infect Dis 2006;194:594-599.

19. Chen G, Lin W, Shen F, Iloeje UH, London WT, Evans AA. Past HBV viral load as predictor of mortality and morbidity from HCC and chronic liver disease in a prospective study. Am J Gastroenterol 2006;101:1797-1803.

20. Yu MW, Yeh SH, Chen PJ, Liaw YF, Lin CL, Liu CJ, et al. Hepatitis $B$ virus genotype and DNA level and hepatocellular carcinoma: a prospective study in men. J Natl Cancer Inst 2005;97:265-272.

21. Chan HL, Thompson A, Martinot-Peignoux M, Piratvisuth $T$, Cornberg M, Brunetto MR, et al. Hepatitis B surface antigen quantifica $\neg$ tion: why and how to use it in 2011 - a core group report. J Hepatol 2011;55:1121-1131.

22. Su TH, Hsu CS, Chen CL, Liu CH, Huang YW, Tseng TC, et al. Serum hepatitis $B$ surface antigen concentration correlates with HBV DNA level in patients with chronic hepatitis B. Antivir Ther 2010;15:11331139.

23. Brunetto MR, Oliveri F, Colombatto P, Moriconi F, Ciccorossi P, Coco $B$, et al. Hepatitis B surface antigen serum levels help to distinguish active from inactive hepatitis B virus genotype D carriers. Gastroenterology 2010;139:483-490.

24. Tseng TC, Liu CJ, Su TH, Wang CC, Chen CL, Chen PJ, et al. Serum hepatitis $B$ surface antigen levels predict surface antigen loss in hepatitis B e antigen seroconverters. Gastroenterology 2011;141:517525.

25. Tseng TC, Liu CJ, Yang HC, Su TH, Wang CC, Chen CL, et al. Determinants of spontaneous surface antigen loss in hepatitis $B$ e antigen-negative patients with a low viral load. Hepatology 2012;55:6876.

26. Lee $M H$, Yang HI, Liu J, Batrla-Utermann R, Jen CL, Iloeje UH, et al. Prediction models of long-term cirrhosis and hepatocellular carcinoma risk in chronic hepatitis B patients: risk scores integrating host and virus profiles. Hepatology 2013;58:546-554.

27. Tseng TC, Liu CJ, Yang HC, Su TH, Wang CC, Chen CL, et al. High levels of hepatitis $B$ surface antigen increase risk of hepatocel-
Iular carcinoma in patients with low HBV load. Gastroenterology 2012;142:1140-1149.

28. Chen JD, Yang HI, Iloeje UH, You SL, Lu SN, Wang LY, et al. Carriers of inactive hepatitis $B$ virus are still at risk for hepatocellular carcinoma and liver-related death. Gastroenterology 2010;138:17471754.

29. Tseng TC, Liu CJ, Yang HC, Su TH, Wang CC, Chen CL, et al. Serum hepatitis $B$ surface antigen levels help predict disease progression in patients with low HBV loads. Hepatology 2013;57:441-450.

30. Tseng TC, Liu CJ, Yang WT, Chen CL, Yang HC, Su TH, et al. Hepatitis $B$ surface antigen level complements viral load in predicting viral reactivation in spontaneous HBeAg seroconverters. J Gastroenterol Hepatol 2014;29:1242-1249.

31. Wen WH, Chang MH, Zhao LL, Ni YH, Hsu HY, Wu JF, et al. Motherto-infant transmission of hepatitis B virus infection: significance of maternal viral load and strategies for intervention. J Hepatol 2013;59:24-30.

32. Wen WH, Huang CW, Chie WC, Yeung CY, Zhao LL, Lin WT, et al. Quantitative maternal hepatitis B surface antigen predicts maternally transmitted hepatitis B virus infection. Hepatology 2016;64:1451 1461.

33. Pan CQ, Duan Z, Dai E, Zhang S, Han G, Wang Y, et al; Tenofovir to prevent hepatitis $B$ transmission in mothers with high viral load. N Engl J Med 2016;374:2324-2334.

34. Kimura T, Rokuhara A, Sakamoto Y, Yagi S, Tanaka E, Kiyosawa $K$, et al. Sensitive enzyme immunoassay for hepatitis B virus corerelated antigens and their correlation to virus load. J Clin Microbiol 2002;40:439-445.

35. Song G, Yang R, Rao H, Feng B, Ma H, Jin Q, et al. Serum HBV corerelated antigen is a good predictor for spontaneous HBeAg seroconversion in chronic hepatitis B patients. J Med Virol 2016 Aug 9. [Epub ahead of print]

36. Tanaka E, Matsumoto A, Suzuki F, Kobayashi M, Mizokami M, Tanaka $Y$, et al. Measurement of hepatitis $B$ virus core-related antigen is valuable for identifying patients who are at low risk of lamivudine resistance. Liver Int 2006;26:90-96.

37. Wong DK, Tanaka Y, Lai CL, Mizokami M, Fung J, Yuen MF. Hepatitis $B$ virus core-related antigens as markers for monitoring chronic hepatitis B infection. J Clin Microbiol 2007;45:3942-3947.

38. Suzuki F, Miyakoshi H, Kobayashi M, Kumada H. Correlation between serum hepatitis $B$ virus core-related antigen and intrahepatic covalently closed circular DNA in chronic hepatitis B patients. J Med Virol 2009;81:27-33.

39. Maasoumy B, Wiegand SB, Jaroszewicz J, Bremer B, Lehmann P, De-

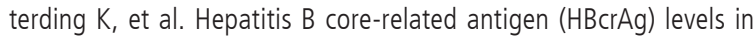
the natural history of hepatitis $B$ virus infection in a large European cohort predominantly infected with genotypes A and D. Clin Microbiol Infect 2015;21:606.e1-e10. 
40. Kumada T, Toyoda H, Tada T, Kiriyama S, Tanikawa M, Hisanaga $Y$, et al. Effect of nucleos(t)ide analogue therapy on hepatocarcinogenesis in chronic hepatitis B patients: a propensity score analysis. J Hepatol 2013;58:427-433.

41. Honda M, Shirasaki T, Terashima T, Kawaguchi K, Nakamura M, Oishi $\mathrm{N}$, et al. HBcrAg during nucleos(t)ide analog therapy are related to intra-hepatic HBV replication and development of hepatocellular carcinoma. J Infect Dis 2016;213:1096-1106.

42. Tada T, Kumada T, Toyoda H, Kiriyama S, Tanikawa M, Hisanaga $Y$, et al. HBcrAg predicts hepatocellular carcinoma development: An analysis using time-dependent receiver operating characteristics. J Hepatol 2016;65:48-56.

43. Li A, Yuan Q, Huang Z, Fan J, Guo R, Lou B, et al. Novel double antigen sandwich immunoassay for human hepatitis $B$ core antibody. Clin Vaccine Immunol 2010;17:464-469.

44. Jia W, Song LW, Fang YQ, Wu XF, Liu DY, Xu C, et al. Antibody to hepatitis $B$ core antigen levels in the natural history of chronic hepatitis B: a prospective observational study. Medicine 2014;93:e322.

45. Yuan Q, Song LW, Liu CJ, Li Z, Liu PG, Huang CH, et al. Quantitative hepatitis $\mathrm{B}$ core antibody level may help predict treatment response in chronic hepatitis B patients. Gut 2013;62:182-184.

46. Fan R, Sun J, Yuan Q, Xie Q, Bai X, Ning Q, et al. Baseline quantitative hepatitis $B$ core antibody titre alone strongly predicts $\mathrm{HBeAg}$ seroconversion across chronic hepatitis B patients treated with peginterferon or nucleos(t)ide analogues. Gut 2016;65:313-320.

47. Liu CJ, Kao JH. Global perspective on the natural history of chronic hepatitis B: role of hepatitis B virus genotypes A to J. Semin Liver Dis 2013;33:97-102.

48. Lin CL, Kao JH. HBV Genotypes and Variants. Cold Spring Harb Perspect Med 2015;5:a021436.

49. Kao JH, Chen PJ, Lai MY, Chen DS. Hepatitis B virus genotypes and spontaneous hepatitis B e antigen seroconversion in Taiwanese hepatitis Bcarriers. J Med Virol 2004;72:363-369.

50. Chu CJ, Hussain M, Lok AS. Hepatitis B virus genotype B is associated with earlier HBeAg seroconversion compared with hepatitis $B$ virus genotype C. Gastroenterology 2002;122:1756-1762.

51. Ni YH, Chang MH, Wang KJ, Hsu HY, Chen HL, Kao JH, et al. Clinical relevance of hepatitis $B$ virus genotype in children with chronic infection and hepatocellular carcinoma. Gastroenterology 2004;127:1733-1738.

52. Sanchez-Tapias JM, Costa J, Mas A, Bruguera M, Rodés J. Influence of hepatitis $B$ virus genotype on the long-term outcome of chronic hepatitis B in western patients. Gastroenterology 2002;123:18481856.

53. Kao JH, Chen PJ, Lai MY, Chen DS. Hepatitis B genotypes correlate with clinical outcomes in patients with chronic hepatitis B. Gastroenterology 2000;118:554-559.

54. Yang HI, Yeh SH, Chen PJ, lloeje UH, Jen CL, Su J, et al. Associations between hepatitis B virus genotype and mutants and the risk of hepatocellular carcinoma. J Natl Cancer Inst 2008;100:1134-1143.

55. Yin J, Zhang H, Li C, Gao C, He Y, Zhai Y, et al. Role of hepatitis $B$ virus genotype mixture, subgenotypes $C 2$ and $B 2$ on hepatocellular carcinoma: compared with chronic hepatitis $B$ and asymptomatic carrier state in the same area. Carcinogenesis 2008;29:1685-1691.

56. Thakur V, Guptan RC, Kazim SN, Malhotra V, Sarin SK. Profile, spectrum and significance of HBV genotypes in chronic liver disease patients in the Indian subcontinent. J Gastroenterol Hepatol 2002;17:165-170.

57. Livingston SE, Simonetti J, McMahon B, Bulkow LR, Hurlburt KJ, Homan $C E$, et al. Hepatitis B virus genotypes in Alaska Native people with hepatocellular carcinoma: preponderance of genotype $F$. J Infect Dis 2007;195:5-11.

58. Shimakawa Y, Lemoine M, Njai HF, Bottomley C, Ndow G, Goldin $R D$, et al. Natural history of chronic HBV infection in West Africa: a longitudinal population-based study from The Gambia. Gut 2015 Jul 16. [Epub ahead of print]

59. Kao JH, Chen PJ, Lai MY, Chen DS. Basal core promoter mutations of hepatitis $B$ virus increase the risk of hepatocellular carcinoma in hepatitis B carriers. Gastroenterology 2003;124:327-334.

60. Lin CL, Liao LY, Wang CS, Chen PJ, Lai MY, Chen DS, et al. Basal core-promoter mutant of hepatitis $B$ virus and progression of liver disease in hepatitis B e antigen-negative chronic hepatitis B. Liver Int 2005;25:564-570.

61. Yang HI, Yeh SH, Chen PJ, Iloeje UH, Jen CL, Su J, et al. Associations between hepatitis $B$ virus genotype and mutants and the risk of he $\neg$ patocellular carcinoma. J Natl Cancer Inst 2008;100:1134-1143.

62. Liu S, Zhang H, Gu C, Yin J, He Y, Xie J, et al. Associations between hepatitis $B$ virus mutations and the risk of hepatocellular carcinoma: a meta-analysis. J Natl Cancer Inst 2009;101:1066-1082.

63. Tseng TC, Liu CJ, Yang HC, Chen CL, Yang WT, Tsai CS, et al. Higher proportion of viral basal core promoter mutant increases the risk of liver cirrhosis in hepatitis B carriers. Gut 2015;64:292-302.

64. Wang HC, Huang W, Lai MD, Su IJ. Hepatitis B virus pre-S mutants, endoplasmic reticulum stress and hepatocarcinogenesis. Cancer Sci 2006;97:683-688.

65. Su IJ, Wang LH, Hsieh WC, Wu HC, Teng CF, Tsai HW, et al. The emerging role of hepatitis $B$ virus pre-S2 deletion mutant proteins in HBV tumorigenesis. J Biomed Sci 2014;21:98.

66. Lin CL, Liu CH, Chen Wendy, Huang WL, Chen PJ, Lai MY, et al. Association of pre-S deletion mutant of hepatitis $B$ virus with risk of hepatocellular carcinoma. J Gastroenterol Hepatol 2007;22:10981103.

67. Chen $\mathrm{CH}$, Hung $\mathrm{CH}$, Lee $\mathrm{CM}$, Hu TH, Wang JH, Wang JC, et al. Pre-S deletion and complex mutations of hepatitis $B$ virus related to advanced liver disease in $\mathrm{HBeAg}$-negative patients. Gastroenterology 2007;133:1466-1474. 
68. Chen BF. Different pre-S deletion patterns and their association with hepatitis B virus genotypes. World J Gastroenterol 2016;22:80418049.

69. Wang C, Teng Z, Zhu Y, Zhao AZ, Sun C. Associations between pre$S$ deletion mutation of hepatitis $B$ virus and risk of hepatocellular carcinoma in the Asian population: A meta-analysis. Med Sci Monit 2015;21:1072-1077.

70. Lok AS. Hepatitis B: liver fibrosis and hepatocellular carcinoma. Gastroenterol Clin Biol 2009;33:911-915.

71. Sebastiani G. Non-invasive assessment of liver fibrosis in chronic liver diseases: Implementation in clinical practice and decisional algorithms. World J Gastroenterol 2009;15:2190-2203.

72. Lin CL, Liu CH, Wang CC, Liang CC, Su TH, Liu CJ, et al. Serum biomarkers predictive of significant fibrosis and cirrhosis in chronic hepatitis B. J Clin Gastroenterol 2015;49:705-713.

73. Huang H, Sun Z, Pan H, Chen M, Tong Y, Zhang J, et al. Serum metabolomic signatures discriminate early liver inflammation and fibrosis stages in patients with chronic hepatitis B. Sci Rep 2016 Aug 8;6:30853.

74. Kao JH, Chen PJ, Chen DS. Recent advances in the research of hepatitis B virus-related hepatocellular carcinoma: epidemiologic and molecular biological aspects. Adv Cancer Res 2010;108:21-72.

75. Eslam M, Hashem AM, Leung R, Romero-Gomez M, Berg T, Dore GJ, et al. Interferon-lambda rs12979860 genotype and liver fibrosis in viral and nonviral chronic liver disease. Nat Commun 2015;6:6422.

76. Kamatani Y, Wattanapokayakit S, Ochi H, Kawaguchi T, Takahashi A, Hosono $N$, et al. A genome-wide association study identifies variants in the HLA-DP locus associated with chronic hepatitis B in Asians. Nat Genet 2009;41:591-595.

77. Cheng HR, Liu CJ, Tseng TC, Su TH, Yang HI, Chen CJ, et al. Host genetic factors affecting spontaneous $\mathrm{HBsAg}$ seroclearance in chronic hepatitis B patients. PLoS One 2013;8:e53008.

78. Yan H, Zhong G, Xu G, He W, Jing Z, Gao Z, et al. Sodium taurocholate cotransporting polypeptide is a functional receptor for human hepatitis B and D virus. ELife 2012;1:e00049.

79. Hu HH, Liu J, Lin YL, Luo WS, Chu YJ, Chang CL, et al; The rs2296651 (S267F) variant on NTCP (SLC10A1) is inversely associated with chronic hepatitis $B$ and progression to cirrhosis and hepatocellular carcinoma in patients with chronic hepatitis B. Gut 2016;65:1514-1521.

80. Zeybel M, Hardy T, Robinson SM, Fox C, Anstee QM, Ness T, et al. Differential DNA methylation of genes involved in fibrosis progression in non-alcoholic fatty liver disease and alcoholic liver disease. Clin Epigenetics 2015;7:25.

81. Zeybel M, Vatansever S, Hardy T, Sarı AA, Cakalağaoğlu F, Avc1 A, et al. DNA methylation profiling identifies novel markers of progression in hepatitis B-related chronic liver disease. Clin Epigenetics 2016;8:48 